\title{
Benefits of Joint Exercise in the Practice of Classical Yoga
}

\author{
Chandra Nanthakumar* \\ Faculty of University Foundation Studies, HELP University, Malaysia
}

Submission: May 25, 2018; Published: August 17, 2018

*Corresponding author: Chandra Nanthakumar, Faculty of University Foundation Studies, HELP University, Bukit Damansara, 50490 Kuala Lumpur, Malaysia; Email: chandratk@help.edu.my

Keywords: Joint Exercise; Classical Yoga; Complementary and alternative medicine; Posture; Pawanmuktasana; Energy locks; Vertebrae

\section{Mini Review}

Yoga, which refers to the union of the body and mind, is a science of right living. This meditative movement has become prominent as therapy in the science of complementary and alternative medicine. While maintaining its underlying principles, the number of variations and styles in yoga have mushroomed over the last two decades.

Unlike many other types of sports, yoga works on the physical, mental, emotional and psychic planes. This explains why the entire body must be mentally and physically prepared before one indulges in any type of asana (posture) be it a beginner or advanced posture. It is imperative for one to also understand that yoga is not a form of exercise but merely a system which involves subtle processes to help manipulate the energy within the biological system.

Therefore, in a classical yoga session, the preparation of the body and mind begins with the joint exercise or simply known as the Pawanmuktasana series in Sanskrit. This series consists of extremely non-challenging postures, but they should be done with awareness due to its innate characteristics. Each and every movement made by the body influences the energy flow throughout the entire anatomy. It is so crucial that the Pawanmuktasana series be done prior to any other challenging postures. Unknown to many modern day yoga practitioners, this series of asanas is so useful as it opens all the major joints and relaxes the muscles of the body [1]. The beauty about this series is that it can be practiced by anyone, young or old, beginner or advanced.

From the etymological point of view, the word pawanmuktasana denotes three aspects which are pawana, mukta and asana. While pawana refers to wind or vital breath, mukta and asana refer to the release and the pose respectively. Simply put, the Pawanmuktasana series or the joint exercise connotes the freeing of wind through a series of asanas. The freeing of the wind helps eliminate blockages which may obstruct the free flow of energy in the entire body and mind. Swami Satyananda Saraswati from the Bihar School of Yoga classified this series of asanas into three distinct groups namely anti-rheumatic, digestive or abdominal, and shakti bandha (energy locks) [2]. While the anti-rheumatic group of asanas help loosen the joints of the body, the digestive and shakti bandha groups of asanas help strengthen the digestive system and improve the energy flow within the body respectively. The profound benefits of the Pawanmuktasana series are discussed in detail in the following paragraphs.

Firstly, the effect of the pawanmuktasana series is seen in the synovial fluid. Found in the joints such as the knees, hips, and elbows, this fluid together with the hyaline cartilage, allows smooth painless movements of the bones. However, this fluid is not found in between the discs in the vertebrae, neither is it found in the sacroiliac joints in the back of the pelvis [1]. This explains why movements in these joints are more restricted compared to the others. The practice of the pawanmuktasana series, which are coordinated with breath, help promote the flow of the synovial fluid to the joints making them supple.

The pawanmuktasana series also helps in strengthening the joint-supporting muscles. In fact, it prepares the body for higher level asanas. If performed correctly, the series is of utmost importance in promoting flexibility in the joints and removing hardness of the muscles [3]. Yoga practitioners should not forego this series as the subtle effect of this extremely easy practice brings about positive effects to the entire body and mind.

Last but not least, the pawanmuktasana series is also employed as a tool in yogic management of various disorders [2] The naïve and the ignorant suffering from modern-day illnesses 
which are psychosomatic in nature, tend to be lured into drugs for treatment. While some drugs may provide immediate relief, it may be wise to note that drug treatment of many illnesses is symptomatic. This simply implies that the root of the disease is most of the time not addressed. That is the reason why many patients keep going back to the hospital for more and more medication. Swami Satyananda Saraswati has reported that the practice of the pawanmuktasana series has a positive impact on a range of disorders from arthritis to heart ailments to even hypertension [2]. This series, if performed mindfully, not only relaxes the muscles of the body, but also the impulses that travel back to the brain. By synchronizing the movement of the asanas with breath, the attentive faculty of the mind is made active and is not allowed to wander. The autonomic nerves will be normalized, and the hormonal functions and activities of internal organs will be regulated [2]. These findings concur with that of Motoyama [4], who advocated that the pawanmuktasana series be performed before any other asanas as they are preparatory work for the awakening the chakras, the energy points. He purported that the distribution of prana, which is the life force, and heat is enhanced as a result of the joint exercise.
In summary, it is strongly recommended that a yoga class or session begin with the pawanmuktasana series. It has been established that consistent practice of the three groups of asanas in this series over a duration of a couple of months will bring about not only profound relaxation, but also toning of the entire psycho-physiological structure [2]. While working through these joint movements, one should be mindful of each and every asana performed. Performing the asanas quickly without awareness may be futile or it may bring about more harm than good. The crucial aspect here is to move with the breath and to breathe with awareness.

\section{References}

1. Stanfield K (2013) 3 ways yoga improves your joint system and skeletal structure.

2. Saraswati SS (1969) Asana, pranayama, mudra bandha. Munger, Bihar: Yoga Publications Trust

3. Clark B (2012) The complete guide to yin yoga: The philosophy and practice of yin yoga. (Revised ed.) White Cloud Press.

4. Motoyama H (2003) Theories of the chakras: Bridge to higher consciousness, New Age Books.

\section{Your next submission with Juniper Publishers will reach you the below assets}

- Quality Editorial service

- Swift Peer Review

- Reprints availability

- E-prints Service

- Manuscript Podcast for convenient understanding

- Global attainment for your research

- Manuscript accessibility in different formats ( Pdf, E-pub, Full Text, Audio)

- Unceasing customer service

Track the below URL for one-step submission https://juniperpublishers.com/online-submission.php 